\title{
ANALISIS PERBANDINGAN HARGA POKOK PRODUKSI DENGAN METODE FULL COSTING DAN METODE ACTIVITY BASED COSTING DALAM MENETAPKAN HARGA JUAL RUKO PADA PT. MEGASURYA NUSALESTARI
}

\author{
Sri Indriani Sugawa ${ }^{1}$, Ventje Ilat ${ }^{2}$, Meily Kalalo ${ }^{3}$ \\ ${ }^{1,2,3}$ Jurusan Akuntansi, Fakultas Ekonomi dan Bisnis, Universitas Sam Ratulangi, Jl. Kampus Bahu, Manado, \\ 95115, Indonesia \\ E-mail : sri.sugawa@gmail.com
}

\begin{abstract}
Cost of goods means the amount of expenses and expenses that are allowed directly or indirectly to produce goods or services in conditions and places where they can be used or sold. PT. Megasurya Nusalestari uses the Full Costing Method to calculate the cost of production in making a decision to determine the selling price of a shophouse. Actvity Based Costing method is a cost information system that is oriented to providing complete information about activities. This study aims to analyze the comparison of cost of goods manufactured using the full costing method and the activity based costing method to determining the selling price of a shophouse. This type of research used in this thesis research is a comparative descriptive method that is comparing the similarities and differences between two or more facts and the nature of objects that are examined based on a certain frame of mind. The results of the study obtained that the activity based costing method produces more accurate data in each loading of resources in the shophouse production process at PT. Megasurya Nusalestari, so that the selling price generated by the full costing method is higher for the standard type, but for the corner and middle type types the resulting selling price is lower than the activity based costing method, it is because the full costing method imposes factory overhead costs on each product is only charged to one cost driver. Keywords: Full Costing Method, Activity Based Costing Method, Selling Price
\end{abstract}

\section{PENDAHULUAN}

Perekenomian yang berkembang semakin pesat memungkinkan perusahaan untuk terus berinovasi dalam membangun pilar-pilar perekonomian jangka panjang, salah satunya adalah bisnis yang bergerak dibidang konstruksi dan property. Jenis bisnis konstruksi dan properti yang sedang banyak diminati adalah Ruko atau Rumah Toko yang dapat diperjual belikan maupun disewa. Ruko biasanya diminati pelaku bisnis yang memiliki usaha toko yang cukup besar tapi juga bagian lain dari bangunan masih bisa dijadikan sebagai tempat tinggal yang nyaman. Dengan demikian, bangunan ruko ini biasanya merupakan bangunan toko di bagian depan dan bangunan rumah di bagian belakang. Perusahaan kecil biasanya menyewa ruko untuk dijadikan kantor . Itulah mengapa bisnis jual beli ruko mulai diminati para pebisnis konstruksi dan properti.

Dalam menghitung harga jual terdapat unsur biaya penuh atau full costing yang merupakan metode untuk menghitung harga pokok produksi dimana dalam metode ini mencakup biaya- biaya bahan baku, biaya tenaga kerja langsung, biaya overhead pabrik variabel dan biaya overhead pabrik tetap, ditambah dengan biaya non-produksi yaitu biaya pemasaran, biaya administrasi \& umum, kemudian ditambahkan dengan persentase laba yang diharapkan PT. Megasurya Nusalestari merupakan perusahaan yang bergerak dibidang property seperti menjual maupun sewa-menyewa ruko, kios, dan lahan yang sangat di kenal dengan nama Kawasan Megamas Manado. Dalam menentukan harga pokok produksi ruko, PT. Megasurya Nusalestari telah menggunakan Metode Full Costing. biaya-biaya yang 
terkandung dalam proses pembangunan ruko yang dihitung perusahaan menggunakan metode full costing yang terdiri dari biaya bahan baku langsung dan biaya tenaga kerja langsung.

Metode Acitivyty Based Costing adalah salah satu metode atau sistem yang ada di akuntansi biaya yang dapat memberikan informasi atau data dari hasil perhitungan secara akurat yang menulusuri kesetiap proses produksi sehingga dari informasi tersebut dapat dijadikan alat untuk pengambilan keputusan dalan menetapkan harga jual ruko. Dibandingkan dengan metode full costing, metode activity based costing mencakup lebih menyeluruh tentang penerapan biaya. Metode activity based costing ini menjelaskan tentang biaya-biaya aktivitas yang dapat ditelusuri untuk memproduksi suatu produk seperti biaya pengawas, biaya desain bangunan, biaya alat pembantu, dan biaya kepengurusan surat-surat. Proses pembangunan yang mengestimasi biaya bahan, jumlah tenaga kerja serta biaya overhead yang akan timbul saat proyek dilaksanakan. Dengan demikian setiap proses pembangunan konstruksi memiliki karakteristik, tingkat kompleksitas, dan volume yang berbeda. Sehingga PT. Megasurya Nusalestari membutuhkan sebuah metode dalam menghitung harga pokok pembangunan rumah toko atau ruko dimana dalam proses perhitungan tersebut membebankan biaya tidak langsung yaitu dengan menggunakan metode activity based costing.

\section{TINJAUAN PUSTAKA}

Pengertian Akuntansi Manajemen. Sadeli (2014) mendefinisikan bahawa akuntansi merupakan sebuah proses dalam mengidentifikasi, mengukur serta melaporkan informasiinformasi ekonomi yang berguna dalam pertimbangan guna mengambil keputusan yang tepat untuk pemakai dari laporan keuangan.. Hansen dan Moewan (2013) menyatakan bahwa akuntansi manajemen yang memiliki proses yaitu mengidentifikasi, mengumpukan, mengukur, serta mengklasifikasiki informasi-informasi yang sekiranya bermanfaat bagi pihak internal perusahaan dalam proses pengambilan keputusan.

Konsep Bisnis Konstruksi dan Properti. Properti ini berhubungan dengan tanah atau lahan, tempat tinggak serta jenis perkantoran dan jenis bangunan yang dikomersilkan. Jadi bisnis property ini juga dapat diartikan sebagai tempat pertukaran atas barang, jasa maupun uang yang berkaitan dengan tanah, tempat tinggal.

\section{Konsep Akuntansi Biaya}

Pengertian Akuntansi Biaya. Menurut Sadeli (2014) bahwa akuntansi biaya lebih menekankan permasalahan ke penetapan serta pengendalian atas biaya, terutama berhubungan dengan biaya produksi suatu barang. Kemudian akuntansi biaya juga membantu pihak manajemen dalam perencanaan maupun pengawasan mengenai biaya dari proses produksi. Akuntasi biaya memiliki fungsi utama yaitu mengumpulkan serta menganalisis data biaya, seperti data aktual ataupun data proyeksi.

\section{Biaya (Cost)}

Pengertian Biaya. Biaya menurut Mulyadi (2015) adalah sebuah pengorbanan atas sumber ekonomi yang dapat diukur dalam satuang moneter atau uang, dimana merupakan transaksi yang telah terjadi ataupun kemungkinan transaksi dimasa yang akan datang guna mencapai tujuan tertentu.

Klasifikasi Biaya. Klasifikasi Biaya Menurut Objek Biaya :

1. Biaya Langsung merupakan biaya-biaya yang sekiranya dapat dengan mudah dilacak ke objek biaya

2. Biaya Tidak Langsung adalah pengorbanan ekonomi yang tidak dapat dengan mudah dan akurat dilacak ke objek biaya.

Klasifikasi Biaya Menurut Waktu Pengakuan/Laporan Keuangan : 
1. Biaya Produksi adalah biaya yang dikeluarkan terkait dengan proses produksi suatu produk

2. Biaya Non Produksi adalah biaya yang dikeluarkan perusahaan terkait dengan perencanaan, pengembangan, pemasaran serta administrasi umum.

Klasifikasi Biaya Menurut Perilaku Biaya/Volume Produksi

1. Biaya Tetap adalah jumlah biaya yang tidak dipengaruhi atas besaran jumlah output atau produksi.

2. Biaya Variabel merupakan sejumlah biaya yang dapat berubah-ubah tergantung dari seberapa banyak jumlah yang diproduksi.

3. Biaya Campuran adalah biaya yang memiliki komponen biaya tetap dan biaya variable.

Menentukan Harga Pokok Produksi. Harga pokok produksi merupakan sejumlah pengorbanan ekonomi atau biaya yang terkandung dalam persediaan barang jadi sebelum barang tersebut terjual. Adapun metode dalam menghitung harga poko produksi sebagai berikut :

Metode Full Costing. Full costing merupakan salah satu metode dalam menghitung harga pokok produksi yang didalmnya terkandung semua unsur biaya produksi kedalam harga pokok produksi. Pengertian Full costing menurut Mulyadi (2015) adalah metode dalam perhitungan harga pokok produksi, yang membebankan seluruh biaya-biaya produksi, yang terdiri dari biaya bahan baku, biaya tenaga kerja langsung, biaya overhead pabrik, maupun biaya tetap ataupun biaya variable.

Metode Activity Based Costing. Siregar dkk (2014) mendefinisikan bahwa metode activity based costing adalah metode dalam penentuan biaya dari produk yang pembebanan biaya tidak langung atau biaya overhead nya didasarkan atas aktivitas-aktivitas yang dilaksanakan selama proses produksi. Activity based costing adalah sebuah sistem atau metode yang dirancang guna memberikan informasi atas hasil perhitungan bagi pihak manajemen perusahaan yang mungkin akan mempengaruhi biaya tetap.

Harga Jual. Kotler dan Armstrong (2014) menerangkan bahwa harga atau price merupakan jumlah dari nilai uang yang ditukar konsumen atas manfaat ekonomi seperti barang atau jasa tersebut. Salman (2013) menyatakan bahwa harga jual produk yang tepat sangat ditentukan oleh keberhasilan dalam menentukan biaya produk yang tepat, sehingga harga jual produk yang ditawarkan dapat menutupi semua biaya dan mampu menghasilkan laba. Harga jual adalah sejumlah besaran uang yang mungkin ditambah dengan beberapa produk yang berguna untuk mendapatkan sejumlah kombinasi atas barang ataupun jasa pelayanan. Penentuan dari harga jual adalah salah satu metode dari pengambulan keputusan pihaj manajemen untuk kelangsungyan hidup perusahaan (Sodikin, 2015).

Penelitian Terdahulu. Arofah Sholihah, Endang Masitoh, dan Siti Nurlela (2017) menunjukan hasil perhitungan menggunakan metode biaya berdasarkan aktivitas (activity based costing) lebih kecil dibandingkan dengan metode yang digunakan oleh pihak manajemen hotel, namun untuk satu tipe kama hasilnya lebih besar. Erni Suryandari, Susanto, dan Muhammad Ali Aqsa (2006) memberikan hasil ini bahwa terdapat pengaruh yang signifikan antara metode $A B C$ pada berkembangnya kinerja dari pihak perusahaan, dimana hal lain menunjukan bahwa inisiatif lainnya tidak memberikan pengaruh yang cukup besar terhadap kinerja dari keuangan yang ada. Dwi Sulami (2017) hasil dari penelitian ini menunjukkan bahwa ada perbedaan pengitungan beban pokok produksi koperasi dengan metode full costing. 


\section{METODE PENELITIAN}

Jenis Penelitian. Jenis penelitian yang digunakan dalam penelitian ini adalah penelitian deskriptif komparatif. Penelitian komparatif adalah penelitian yang bersifat untuk sekiranya memberikan perbandingan maupun perusamaan yang ada antara dua atau lebih dari fakta yang ada dalam objek penelitian berlandaskan pada kerangka sebuah pemikiran tertentu.

Tempat dan Waktu Penelitian. Objek penelitian pada PT Megasurya Nusalestari sebagai salah satu Perusahaan yang bergerak di bidang Konstruksi dan Property. PT. Megasurya Nusalestari berlokasi di Manado, Kawasan Megamas Blok 2B2 No.1 jln. Piere Tendean Boulevard. Penelitian ini dilakukan mulai dari bulan April 2018 sampai bulan Mei 2018.

\section{Metode Pengumpulan Data}

Jenis Data. Data Kuantitatif yang ada dalam penelitian ini berupa RAB (Rencana Anggaran Biaya) pembangunan ruko yang memuat tentang semua biaya serta harga jual yang telah ditetapkan perusahaan, sedangkan Data Kualitatif berupa hasil dari wawancara peneliti dengan pihak perusahaan.

Sumber Data. Sumber data yang digunakan oleh peneliti dalam penelitian ini adalah sumber data primer yang diperoleh dan dikumpulkan langsung dari perusahaan PT. Megasurya Nusalestari. Sumber data primer ini berupa rencana anggaran biaya, data harga jual ruko yang saat ini diterapkan, persentase laba yang diharapkan perusahaan, dan mengenai deskripsi perusahaan.

\section{Teknik Pengumpulan Data}

1. Wawancara yang peneliti lakukan dengan berhadapan langsung dengan pihak perusahaan dengan kegitan atas tanya jawab mengenai data-data yang sekiranya diperlukan.

2. Observasi merupakan sebuah metode yang cukup luas karena kegiatan ini melibatkan beberapa factor dalam proses pelaksanaannya.

3. Dokumentasi merupakan metode yang dilakukan dengan mencari informasi dari bukubuku maupun literature lainnya yang memiliki hubungan dengan masalah yang peneliti teliti.

Metode Analisis. Membandingkan hasil perhitungan harga pokok produksi dengan metode full costing yang telah digunakan oleh perusahaan dengan metode activity based costing.

\section{HASIL ANALISIS DAN PEMBAHASAN}

\subsection{Hasil analisis}

Perhitungan Harga Pokok Produksi. Metode menghitung harga pokok prouksi yang telah digunakan oleh perusahaan adalah metode biaya penuh atau metode full costing.

\section{Perhitungan Harga Pokok Produksi Menggunakan Metode Full Costing}

Tabel 1. Prime Cost atau Biaya Utama

\begin{tabular}{llr}
\hline No. & \multicolumn{1}{c}{ Tipe Ruko } & Total Biaya \\
\hline 1 & MEGASMART 2F2 Tipe Standard (21 Unit) & Rp.10,382,835,138.71 \\
2 & MEGASMART 2F2 Tipe Sudut (2 Unit) & Rp. $1,744,445,419.51$ \\
3 & MEGASMART 2F2 Tipe Tengah (1 Unit) & Rp.999,841,441.78 \\
\hline (Sumber : Data Perusahaan)
\end{tabular}


Tabel 2. Biaya Tidak Langsung (Overhead)

\begin{tabular}{llr}
\hline No. & \multicolumn{1}{c}{ Penggolongan Biaya } & Total Biaya \\
\hline 1 & Biaya Manager Proyek & $\mathrm{Rp} .37,500,000.00$ \\
2 & Biaya Assistant Manager Proyek & $\mathrm{Rp} .30,000,000.00$ \\
3 & Supervisor & $\mathrm{Rp} .30,000,000.00$ \\
4 & Mobilisasi Alat & $\mathrm{Rp} .22,750,000.00$ \\
5 & Pembuatan Sertifikat & $\mathrm{Rp} .44,000,000.00$ \\
6 & Pembuatan IMB & $\mathrm{Rp} .22,000,000.00$ \\
7 & Instalasi Listrik dan Air & $\mathrm{Rp} .10,000,000.00$ \\
8 & Mendesain Bangunan & $\mathrm{Rp} .75,000,000.00$ \\
9 & Maintenance/ Pemeliharaan Bangunan & $\mathrm{Rp} .3,750,000.00$ \\
& Total Biaya & $\mathbf{R p . 2 7 5 , 0 0 0 , 0 0 0 . 0 0}$ \\
& Jumlah Unit & $\mathbf{2 5}$ Unit \\
& Jumlah Biaya per unit & $\mathbf{R p . 1 1 , 0 0 0 , 0 0 0 . 0 0}$ \\
\hline
\end{tabular}

Sumber : Data Diolah

Dari data table 2 dapat dilihat bahwa biaya overhead hanya dibebankan pada satu cost driver saja yaitu jumlah unit (sebanyak 25 unit ruko) apabila menggunakan metode full costing.

Tabel 3. Perhitungan Harga Pokok Produksi

\begin{tabular}{lccr}
\hline \multicolumn{1}{c}{ Tipe Ruko } & Biaya Utama & Biaya Overhad & Harga Pokok Produksi \\
\hline Tipe Standard & Rp.494,420,720.89 & Rp. $11,000,000$ & Rp.505,420,720.89 \\
Tipe Sudut & Rp.872,222,709.76 & Rp. $11,000,000$ & Rp.883,222,709.76 \\
Tipe Tengah & Rp.999,841,441.78 & Rp. $11,000,000$ & Rp. $1,010,841,441.78$ \\
\hline
\end{tabular}

Sumber : Data Diolah

Tabel 4. HPP (harga pokok produksi) Ruko MEGASMART 2F2 - Metode Full Costing

\begin{tabular}{llrrr}
\hline \multirow{2}{*}{ No } & \multirow{2}{*}{ Produk } & \multicolumn{2}{c}{ Harga Pokok Produksi } & \multirow{2}{*}{ Jumlah } \\
\cline { 3 - 4 } & & Bangunan & Tanah & Rp.1,000,420,720.89 \\
\hline 1 & Tipe Standard & Rp.505,420,720.89 & Rp.495,000,000.00 & Rp.1,774,222,709.76 \\
2 & Tipe Sudut & Rp.883,222,709.76 & Rp. $891,000,000.00$ & Rp. 1,700, \\
3 & Tipe Tengah & Rp. $1,010,841,441.78$ & Rp.990,000,000.00 & Rp.2,000,841,441.78 \\
\hline
\end{tabular}

Sumber: Data Diolah

\section{Perhitungan Harga Pokok Produksi Menggunakan Metode Activity Based Costing}

Dalam menghitung harga pokok produksi menggunakan Metode Activity Based Costing, dilakukan dalam beberapa tahap sebagai berikut :

Prosedur Tahap Pertama

1) Penggolongan dari berbagai aktivitas dalam proses produksi

2) Menghubungkan berbagai biaya dengan kelompok aktivitas

3) Menentukan pemicu biaya atau biasanya disebut cost driver

4) Penentuan kelompok-kelompok biaya yang homogeny

5) Penentuan tarif tiap kelompok berdasarkan aktivitas yang ada (pool rate)

Prosedur Tahap Kedua

Menentukan harga pokok produksi yaitu biaya untuk setiap kelompok biaya overhead pabrik. 


\begin{tabular}{lll}
\hline \multicolumn{1}{c}{ Proyek } & \multicolumn{1}{c}{ Tabel 5. Menentukan Pemicu Biaya (Cost Driver) } \\
\hline Pembangunan Ruko & Biaya Manager Proyek & \multicolumn{1}{c}{ Cost Driver } \\
Megasmart 2F2 & Biaya Assistant Manager Proyek & Jumlah Hari \\
Kawasan Megamas & Supervisor & Jumlah Hari \\
Manado & Mendesain Bangunan & Luas Gedung \\
& Mobilisasi Alat & Jumlah Hari \\
& Pembuatan Sertifikat & Luas Tanah \\
& Pembuatan IMB & Luas Tanah \\
& Instalasi Listrik dan Air & Jumlah Hari \\
& Maintenance/ Pemeliharaan Bangunan & Luas Gedung \\
\hline
\end{tabular}

Sumber : Data Diolah

Tabel 6. Pengelompokkan Biaya Yang Homogen (Homogeneous Cost Pool)

\begin{tabular}{|c|c|c|c|c|}
\hline No. & Aktivitas Overhead & $\begin{array}{l}\text { Biaya yang } \\
\text { homogen }\end{array}$ & Cost driver & $\begin{array}{l}\text { Jumlah Biaya } \\
\text { (Dalam Rp) }\end{array}$ \\
\hline \multirow[t]{6}{*}{1} & Aktivitas Berlevel Unit & \multirow{6}{*}{ Pool 1} & & \\
\hline & Biaya Manager Proyek & & Jumlah Hari & $37,500,000.00$ \\
\hline & $\begin{array}{l}\text { Biaya Assistant Manager } \\
\text { Provek }\end{array}$ & & Jumlah Hari & $30,000,000.00$ \\
\hline & $\begin{array}{l}\text { ProyeK } \\
\text { Supervisor }\end{array}$ & & Jumlah Hari & $30,000,000.00$ \\
\hline & Mobilisasi Alat & & Jumlah Hari & $22,750,000.00$ \\
\hline & Instalasi Listrik dan Air & & Jumlah Hari & $10,000,000.00$ \\
\hline \multirow[t]{3}{*}{2} & Aktivitas Berlevel Batch & & & \\
\hline & Pembuatan Sertifikat & \multirow{2}{*}{ Pool 2} & Luas Tanah & $44,000,000.00$ \\
\hline & Pembuatan IMB & & Luas Tanah & $22,000,000.00$ \\
\hline \multirow[t]{2}{*}{3} & Aktivitas Berlevel Produk & & & \\
\hline & Mendesain Bangunan & Pool 3 & Luas Gedung & $75,000,000.00$ \\
\hline \multirow[t]{2}{*}{4} & Aktivitas Berlevel Fasilitas & & & \\
\hline & $\begin{array}{l}\text { Maintenance/Pemeliharaan } \\
\text { Bangunan }\end{array}$ & Pool 4 & Luas Gedung & $3,750,000.00$ \\
\hline
\end{tabular}

Sumber : Data Diolah

Tabel 7. Menghitung Cost Pool (Tarif Kelompok)

\begin{tabular}{|c|c|c|c|c|c|}
\hline \multirow[t]{2}{*}{ No. } & Aktivitas & $\begin{array}{l}\text { Cost } \\
\text { Pool }\end{array}$ & Total Cost Pool & Cost Driver & Pool Rate \\
\hline & $\mathrm{A}$ & $\mathrm{B}$ & $\mathrm{C}$ & $\mathrm{D}$ & $\mathrm{E}=\mathrm{C}: \mathrm{D}$ \\
\hline 1 & $\begin{array}{l}\text { Biaya Manager Proyek } \\
\text { Biaya Assistant } \\
\text { Manager Proyek } \\
\text { Supervisor } \\
\text { Mobilisasi Alat } \\
\text { Instalasi Listrik dan Air }\end{array}$ & 1 & $130,250,000.00$ & $\begin{array}{l}150 \\
\text { Hari Kerja }\end{array}$ & $868,333.33$ \\
\hline 2 & $\begin{array}{l}\text { Pembuatan Sertifikat } \\
\text { Pembuatan IMB }\end{array}$ & 2 & $66,000,000.00$ & $\begin{array}{l}396 \\
\text { luas lahan (m2) }\end{array}$ & $166,666.67$ \\
\hline 3 & Mendesain Bangunan & 3 & $75,000,000.00$ & $\begin{array}{l}7948.5 \\
\text { luas bangunan }(\mathrm{m} 2)\end{array}$ & $9,435.74$ \\
\hline
\end{tabular}

Sumber : Data Diolah 
Tabel 8. Biaya Tidak Langsung (Overhead) MEGASMART 2F2 Tipe Standard

\begin{tabular}{|c|c|c|c|c|c|}
\hline \multirow[t]{2}{*}{ No. } & Aktivitas & $\begin{array}{l}\text { Cost } \\
\text { Pool }\end{array}$ & Pool Rate & Cost Driver & Biaya Overhead \\
\hline & $\mathbf{A}$ & B & C & D & $E=C \times D$ \\
\hline \multirow[t]{3}{*}{1} & $\begin{array}{l}\text { Biaya Manager Proyek } \\
\text { Biaya Assistant } \\
\text { Manager Proyek }\end{array}$ & & & & \\
\hline & Supervisor & 1 & $868,333.33$ & $\begin{array}{r}150 \\
\text { Hari Kerja }\end{array}$ & $130,250,000.00$ \\
\hline & $\begin{array}{l}\text { Mobilisasi Alat } \\
\text { Instalasi Listrik dan } \\
\text { Air }\end{array}$ & & & & \\
\hline \multirow[t]{2}{*}{2} & Pembuatan Sertifikat & & & & \\
\hline & & 2 & $166,666.67$ & $\begin{array}{r}82.5 \\
\text { luas lahan }\left(\mathrm{m}^{2}\right)\end{array}$ & $13,750,000.00$ \\
\hline 3 & $\begin{array}{l}\text { Pembuatan IMB } \\
\text { Mendesain Bangunan } \\
\text { Total Biaya } \\
\text { Jumlah Unit } \\
\text { Biaya Per Unit }\end{array}$ & 3 & $9,435.74$ & 6300 & $\begin{array}{r}59,445,178.34 \\
203,445,178.34 \\
21.00 \\
9,687,865.64\end{array}$ \\
\hline
\end{tabular}

Sumber : Data Diolah

Tabel 9. Biaya Tidak Langsung (Overhead) MEGASMART 2F2 Tipe Sudut

\begin{tabular}{|c|c|c|c|c|c|}
\hline \multirow[t]{2}{*}{ No. } & Aktivitas & $\begin{array}{l}\text { Cost } \\
\text { Pool }\end{array}$ & Pool Rate & Cost Driver & Biaya Overhead \\
\hline & $\mathbf{A}$ & $\mathbf{B}$ & $\mathbf{C}$ & D & $E=C \times D$ \\
\hline \multirow[t]{3}{*}{1} & $\begin{array}{l}\text { Biaya Manager Proyek } \\
\text { Biaya Assistant manager } \\
\text { Proyek }\end{array}$ & & & & \\
\hline & Supervisor & 1 & $868,333.33$ & 150 & $130,250,000.00$ \\
\hline & $\begin{array}{l}\text { Mobilisasi Alat } \\
\text { Instalasi Listrik dan Air }\end{array}$ & & & Hari Kerja & \\
\hline 2 & $\begin{array}{l}\text { Pembuatan Sertifikat } \\
\text { Pembuatan IMB }\end{array}$ & 2 & $166,666.67$ & $\begin{array}{r}148.5 \\
\text { luas lahan }(\mathrm{m} 2)\end{array}$ & $24,750,000.00$ \\
\hline 3 & Mendesain Bangunan & 3 & $9,435.74$ & 1048.5 & $9,893,376.11$ \\
\hline \multicolumn{2}{|c|}{ Total Biaya } & & & & $164,893,376.11$ \\
\hline \multicolumn{2}{|c|}{ Jumlah Unit } & & & & 2 \\
\hline \multicolumn{2}{|c|}{ Biaya Per Unit } & & & & $82,446,688.05$ \\
\hline
\end{tabular}

Sumber : Data Diolah 


\begin{tabular}{|c|c|c|c|c|c|}
\hline \multicolumn{6}{|c|}{ Tabel 10. Biaya Tidak Langsung (Overhead) MEGASMART 2F2 Tipe Tengah } \\
\hline \multirow[t]{2}{*}{ No. } & Aktivitas & $\begin{array}{l}\text { Cost } \\
\text { Pool }\end{array}$ & Pool Rate & Cost Driver & Biaya Overhead \\
\hline & A & B & $\mathbf{C}$ & $\mathbf{D}$ & $\mathbf{E}=\mathbf{C} \times \mathbf{D}$ \\
\hline \multirow[t]{5}{*}{1} & Biaya Manager Proyek & & & & \\
\hline & $\begin{array}{l}\text { Biaya Assistant manager } \\
\text { Proyek }\end{array}$ & & & & \\
\hline & Supervisor & 1 & $868,333.33$ & 150 & $130,250,000.00$ \\
\hline & Mobilisasi Alat & & & Hari Kerja & \\
\hline & $\begin{array}{l}\text { Instalasi Listrik dan Air } \\
\text { Pembuatan Sertifikat }\end{array}$ & 2 & $166,666.67$ & 165 & $27,500,000.00$ \\
\hline 2 & Pembuatan IMB & & & luas lahan (m2) & \\
\hline 3 & Mendesain Bangunan & 3 & $9,435.74$ & 600 & $5,661,445.56$ \\
\hline \multicolumn{2}{|c|}{ Total Biaya } & & & & $163,411,445.56$ \\
\hline \multicolumn{2}{|c|}{ Jumlah Unit } & & & & 1 \\
\hline \multicolumn{2}{|c|}{ Biaya Per Unit } & & & & $163,411,445.56$ \\
\hline
\end{tabular}

Sumber : Data Diolah

Tabel 11. Perhitungan Harga Pokok Produk - Metode Activity Based Costing

\begin{tabular}{llrrr}
\hline No. & \multicolumn{1}{c}{ Elemen Biaya } & Tipe Standard & \multicolumn{1}{c}{ Tipe Sudut } & \multicolumn{1}{c}{ Tipe Tengah } \\
\hline 1 & Biaya Utama/Unit & $494,420,720.89$ & $872,222,709.76$ & $999,841,441.78$ \\
2 & Biaya Overhead & $9,687,865.64$ & $82,446,688.05$ & $163,411,445.56$ \\
& Harga Pokok & $\mathbf{5 0 4 , 1 0 8 , 5 8 6 . 5 3}$ & $\mathbf{9 5 4 , 6 6 9 , 3 9 7 . 8 1}$ & $\mathbf{1 , 1 6 3 , 2 5 2 , 8 8 7 . 3 4}$ \\
\hline
\end{tabular}

Sumber : Data Diolah

Biaya overhead yang diperoleh dengan menggunakan metode activity based costing berbeda dengan metode full costing ini dikarenakan dalam menghitung biaya overhead, metode activity based costing berlandaskan pada beberapa jenis cost driver, apabila dilihat dari Tabel 2 yang hanya berdasarkan jumlah unit, pada table 5 merupakan hasil dari perhitungan tergantung dari luas bangunan, luas lahan, dan hari kerja sehingga memberikan informasi yang berbeda.

Tabel 12. Ruko MEGASMART 2F2 - Metode Activity Based Costing

\begin{tabular}{llrrr}
\hline \multirow{2}{*}{ No } & \multirow{2}{*}{ Produk } & \multicolumn{2}{l}{ Harga Pokok Produksi } & \multicolumn{1}{l}{ Jumlah } \\
\cline { 3 - 4 } & & \multicolumn{1}{c}{ Bangunan } & \multicolumn{1}{c}{ Tanah } & \multicolumn{1}{c}{ (Dalam Rp) } \\
\hline 1 & Tipe Standard & $504,108,586.53$ & $495,000,000.00$ & $999,108,586.53$ \\
2 & Tipe Sudut & $954,669,397.81$ & $891,000,000.00$ & $1,845,669,397.81$ \\
3 & Tipe Tengah & $1,163,252,887.34$ & $990,000,000.00$ & $2,153,252,887.34$ \\
\hline
\end{tabular}

Sumber : Data Diolah

\subsubsection{Perhitungan Harga Jual Ruko}

Dalam perhitungan harga jual, terdapat besaran laba yang ingin diperoleh perusahaan untuk setiap Tipe Ruko, peneliti akan membandingkan harga jual ruko apabila menggunakan pendekatan metode full costing dan metode activity based costing, sebagai berikut : 


\section{Perhitungan Harga Jual Ruko Menggunakan Pendekatan Full Costing \\ Harga Jual Ruko untuk Tipe Standard}

Perhitungan Harga Jual Ruko MEGASMART 2F2 Tipe Standard dengan laba yang diharapkan PT. Megasurya Nusalestari sebesar $41 \%$.

$$
\begin{aligned}
\text { Haga Jual } & =\text { Rp. } 1,000,420,720.89+41 \% \text { x Rp. } 1,000,420,720.89 \\
& =\text { Rp. } 1,000,420,740.89+\text { Rp. } 410,172,495.57 \\
& =\text { Rp. } 1,410,593,216.46 \\
& =\text { Rp. } 1,410,000,000 \text { DIBULATKAN }
\end{aligned}
$$

\section{Harga Jual Ruko untuk Tipe Sudut}

Perhitungan Harga Jual Ruko MEGASMART 2F2 Tipe Sudut dengan laba yang diharapkan PT. Megasurya Nusalestaru sebesar 38\%.

$$
\begin{aligned}
\text { Haga Jual } & =\text { Rp. } 1,774,222,709.76+38 \% \text { x Rp. } 1,774,222,709.76 \\
& =\text { Rp. } 1,774,222,709.76+\text { Rp. } 674,204,629.71 \\
& =\text { Rp. } 2,448,427,339.46 \\
& =\text { Rp. } 2,450,000,000 \text { DIBULATKAN }
\end{aligned}
$$

\section{Harga Jual Ruko untuk Tipe Tengah}

Perhitungan Harga Jual Ruko MEGASMART 2F2 Tipe Sudut dengan laba yang diharapkan PT. Megasurya Nusalestari sebesar $45 \%$.

$$
\begin{aligned}
\text { Haga Jual } & =\text { Rp. 2,000,841,441.78 + 45\% x Rp. 2,000,841,441.78 } \\
& =\text { Rp. 2,000,841,441.78 + Rp. 900,378,648.80 } \\
& =\text { Rp. 2,901,220,090.58 } \\
& =\text { Rp. 2,902,000,000 DIBULATKAN }
\end{aligned}
$$

\section{Perhitungan Harga Jual Ruko Menggunakan Pendekatan Activity Based Costing}

\section{Harga Jual Ruko untuk Tipe Standard}

Perhitungan Harga Jual Ruko dengan pendekatan activity based costing method, MEGASMART 2F2 Tipe Standard dengan laba yang diharapkan PT. Megasurya Nusalestari sebesar $41 \%$.

$$
\begin{aligned}
\text { Haga Jual } & =\text { Rp. } 999,108,586.53+41 \% \times \text { Rp. } 999,108,586.53 \\
& =\text { Rp. } 999,108,586.53+\text { Rp. } 409,634,420.48 \\
& =\text { Rp. } 1,408,743,107.00
\end{aligned}
$$

\section{Harga Jual Ruko untuk Tipe Sudut}

Perhitungan Harga Jual Ruko dengan pendekatan activity based costing method, MEGASMART 2F2 Tipe Sudut dengan laba yang diharapkan PT. Megasurya Nusalestari sebesar $38 \%$.

$$
\begin{aligned}
\text { Haga Jual } & =\text { Rp. } 1,845,669,397.81+38 \% \text { x Rp. } 1,845,669,397.81+ \\
& =\text { Rp. } 1,845,669,397.81+\text { Rp. } 701,354,371.17 \\
& =\text { Rp. } 2,547,023,768.98
\end{aligned}
$$

\section{Harga Jual Ruko untuk Tipe Tengah}

Perhitungan Harga Jual Ruko dengan pendekatan activity based costing method, MEGASMART 2F2 Tipe Tengah dengan laba yang diharapkan PT. Megasurya Nusalestari sebesar $45 \%$.

$$
\begin{aligned}
\text { Haga Jual } & =\text { Rp. } 2,153,252,887.34+45 \% \text { x Rp. } 2,153,252,887.34 \\
& =\text { Rp. } 2,153,252,887.34+\text { Rp. } 968,063,799.30 \\
& =\text { Rp. } 3,122,216,686.64
\end{aligned}
$$

\subsection{Pembahasan}

Harga pokok produksi ruko menurut PT. Megasurya Nusalestari dengan menggunakan metode full costing dimana pemicu biaya hanya dibebankan pada jumlah unit produksi sehingga perusahaan tidak bisa menelaah lebih jauh mengenai sumber-sumber biaya, sedangkan perhitungan menggunakan metode activity based costing biaya overhead 
dibebankan pada cost driver yang bermacam-macam tergantung dengan aktivitas yang terjadi selama dalam proses produksi sehingga hasil perhitungan dengan metode activity based costing lebih akurat dibandingkan dengan hasil perhitungan dengan metode full costing.

Untuk harga jual ruko yang ditetapkan PT. Megasurya Nusalestari yang dihitung berdasarkan harga pokok produksi dengan metode full costing menghasilkan perbedaan apabila dibandingkan dengan perhitungan dari metode activity based costing. Hal ini dikarenakan sumber-sumber biaya dialokasikan secara akurat dengan metode activity based costing tergantung dari aktivitas yang terjadi selama proses produksi sedangkan untuk metode full costing hanya dialokasikan dalam jumlah unit produk tanpa memperhatikan alokasi biaya persetiap luas bangunan, luas lahan, dan jumlah hari. aulana, Dzulkirom dan Dwiatmanto (2016) menunnjukkan temuan yang sama dimana harga pokok sewa kamar dengan perhitungan metode activity based costing mengalami perbedaan dikarenakan pembebanan biaya overhead pada masing-masing produk. Senada dengan penelitian dari Latuconsina dan Hwihanus (2016) bahwa perbandingan harga jual disebabkan karena pembebanan biaya overhead pada masing-masing produk. Sehingga dalam metode activity based costing telah mampu mengalokasikan biaya aktiva kesetiap kamar secara tepat berdasarkan konsumsi masing-masing aktivitas.

\section{KESIMPULAN DAN SARAN}

\subsection{Kesimpulan}

Dalam perhitungan harga pokok produksi dengan menggunakan metode full costing belum memberikan informasi yang akurat dikarenakan dalam pembangunan konstruksi memiliki karakteristik, tingkat kompleksitas, dan volume yang berbeda namun dalam perhitungan metode full costing yang menjadi pemicu biaya hanyalah jumlah unit produksi saja, maka dari itu diperlukan sebuah metode yang menghasilkan perhitungan yang lebih akurat dan kiranya dapat memberikan informasi kepada pihak perusahaan terlebih khusus manajemen perusahaan untuk bisa mengambil keputusan dengan menggunakan Metode Biaya Berdasarkan Aktivitas (activity based costing method). Metode perhitungan biaya berdasarkan aktivitas kiranya bisa memberikan informasi dari hasil perhitungan yang lebih akurat dan menulusuri seluruh sumber daya terhadap penyeybab biaya dalam proses oembangunan gedung ruko di PT. Megasurya Nusalestari. Perhitungan harga jual ruko yang dihasilkan dengan pendekatan Metode Full Costing dan Metode Activity Based Costing memberikan hasil yang berbeda sehingga mempengaruhi laba yang akan diperoleh perusahaan. Metode Activity based costing adalah sebuah sistem atau metode yang dirancang guna memberikan informasi atas hasil perhitungan bagi pihak manajemen perusahaan yang mungkin akan mempengaruhi penetapan harga.

\subsection{Saran}

Adapun saran yang dapat peneliti berikan sebagai masukan untuk PT. Megasurya Nusalestari antara lain :

1. PT. Megasurya Nusalestari sebaiknya mengklasifikasikan jenis-jenis biaya yang ada dalam proses pembangunan ruko sesuai dengan tujuan yang ingin dicapai sehingga informasi atau hasil perhitungan biaya yang telah diberikan bisa menjadi lebih akurat dan memberikan data yang lebih tepat.

2. Pembebanan atas biaya tidak langsung atau biasanya disebut biaya overhead pabrik terhadap rumah took (ruko) sebaiknya dipertimbangkan terlebih dahulu oleh PT.Megasurya Nusalestari atas dasar yang tepat dalam menentukan biaya overhead berdasarkan aktivitas yang dilaksnakan selama pembangunan ruko. hal ini bertujuan agar perusahaan bisa mengetahui besaran biaya yang sebenarnya dikeluarkan untuk satu unit produk dalam hal ini adalah ruko. 
3. PT. Megasurya Nusalestari sebaiknya menggunakan Metode Activity Based Costing untuk dasar menentukan harga jual dikarenakan metode ini memberikan informasi yang lebih akurat mengenai harga pokok produksi karena pembebenan biayanya tidak berdasarkan jumlah unit yang diproduksi melainkan konsumsi sumber daya disetiap aktivitas yang dilakukan dalam memproduksi produk.

\section{DAFTAR PUSTAKA}

Hansen, Mowen. 2013. Akuntansi Manajerial. Salemba Empat. Jakarta.

Kotler, Philip, Gerry Armstrong, 2014: Principle Of Marketing, 15th edition.

Mulyadi, 2015. Akuntansi Biaya. Edisi 5. Yogyakarta: Unit Penerbit dan Percetakan Sekolah Tinggi Ilmu Manajemen YKPN.

Salman, Kausar R. 2013. Akuntansi Biaya: Pendekatan Product Costing. Akademis Permata, Jakarta.

Sadeli, Lili. 2014. Dasar-Dasar Akuntansi. PT. Bumi Aksara, Jakarta.

Siregar, Baldric, dkk. 2014. Akuntansi Biaya. Edisi Dua. Jakarta : Salemba Empat.

Sholihah,A.F., dkk. 2017. Analisis Perbandingan Penentuan Harga Pokok Kamar Hotel Antara Full Costing Dengan Actvitiy Based Costing System (Studi Kasis Pada Hotel Istana Hapsari Sukoharjo). Jurnal Akuntansi dan Pajak Vol. 18 No. 01, Universitas Islam Batik Surakarta. Hal 2-8

Sodikin. 2015. Akuntansi Managemen. UPP STIM YKPN, Yogyakarta.

Sulami, Dwi. 2017. Analisis Metode Full Costing Dalam Penetapan Harga Jual Susu Pada Koperasi Tani Jasa Tirta. Jurnal Vol.10 No.10, Universitas Nusantara PGRI Kediri. Hal. 4-9

Suryandari, E.F. dkk. 2006. Pengaruh Activity Based Costing Terhadap Peningkatan Kinerja Keuangan (Studi Empiris Pada Perusahaan Manufaktur Yang Terdaftar di Bursa Efek Jakarta).Jurnal Akuntansi dan Investasi Volume 7 No. 2 , Universitas Muhammadiyah Yogyakarta. Hal 244-263

Maulana,A.H., dkk. 2016. Analisis Activity Based Costing System (ABC System) Sebagai Dasar Menentukan Harga Poko Kamar Hotel (Studi Kasis Pada Hotel Selecta Kota Batu Tahun 2014).Jurnal Administrasi Bisnis Vol 30, No. 1 . Universitas Brawijaya, Malang. Hal 161-169

Latuconsina, J. U., dan Hwihanus. 2016. Penerapan Metode Activity Based Costing System Dalam Penentuan Tarif Jasa Rawat Inap Pada Rumah Sakit Husada Utama Surabaya. Jurnal Ekonomi Akuntansi Universitas 17 Agustus 1945 Surabaya, Volume 1. Hal 37-50 